\section{Differences of fire activity and their underlying factors among vegetation formations in Greece}

\author{
Fotios Xystrakis, Nikos Koutsias
}

Climate and weather play an important role in shaping fire activity patterns by controlling fuel productivity and fire spread, respectively. Additionally, climate is a key factor controlling primary productivity while different climate zones are expected to support different vegetation formations, that on their turn, include different fuel types. The use, therefore, of an underlying phytogeographical framework would provide more comprehensive outputs in exploring fire activity patterns at national scales, instead of using administrative units that could include various types of non-ecological divisions. Within this concept, we examined the recent fire activity of the main forest formations occurring in Greece and we explored their relationships with various weather parameters and indexes. Correlations of number of fires with weather variables, especially among the vegetation formations that summarize most of the human influence were lax, yet burned area showed significant correlations mainly with fire season precipitation totals. The precipitation related variables generally outperformed the temperature-related variables in correlating with both number of fires and burned area. Climatic indexes, which embody the combined effects of precipitation and air temperature, reflected improved correlations, but not to the extent that could allow for the promotion of their use in further modeling.

Keywords: Fire History, Fire Regime, Potential Natural Vegetation, Time Series

\section{Introduction}

Fire is an important disturbance factor in many terrestrial ecosystems that affects biodiversity and ecosystem functions (Rundel 1981, Cowling et al. 1996, Arianoutsou 2001) and structures plant communities (Bond et al. 2005, Pausas et al. 2008). The effects of fire may be severe, depending on fire frequency and intensity, the regeneration dynamics of vegetation and other local site characteristics like topography (Viedma 2008, Moreira et al. 2011). How important are fires in shaping vegetation patterns is proved by the increase in fire frequency, area burned and fire severity and extension of fire season observed in many areas of the world (Dimitrakopoulos et al. 2011b, Pausas \& Fernandez-Munoz 2012, Zumbrunnen et al. 2012). This is important especially for the Mediterranean region, which is considered

as one of the most fire-prone regions of the world with a remarkably high burned area/ fire ignition index (Moriondo et al. 2006).

Climate and weather play an important role in shaping fire activity patterns, the first by controlling fuel production and the second by affecting fire spread (Littell \& Gwozdz 2011). Among the weather variables that were found to correlate with number of fires and burned area surface, the amount of summer or fire-season rainfall (Viegas \& Viegas 1994, Pausas 2004), annual precipitation (Viegas \& Viegas 1994) and several parameters derived from air temperature (Piñol et al. 1998) are the most important. Aggregation of the above parameters over time (e.g., totals for precipitation or averages for air temperature) often helps in noise reduction when different seasons are considered. For example, it has been shown that total preci-

Department of Environmental and Natural Resources Management, University of loannina, G. Seferi 2, GR-30100 Agrinio (Greece)

@ Fotios Xystrakis (fotios.xystrakis@gmail.com)

Received: Oct 25, 2012 - Accepted: Nov 23, 2012

Citation: Xystrakis F, Koutsias N, 2013. Differences of fire activity and their underlying factors among vegetation formations in Greece. iForest 6: 132-140 [online 2013-04-08] URL: http://www.sisef.it/iforest/contents?id=ifor0837-005

Communicated by: Marco Borghetti pitation over spring may have a positive correlation with burned area, while fire-season precipitation may show a negative correlation (Littell et al. 2009). Moreover, it has been observed that weather indexes combining the effect of simple weather parameters are, conditionally, better correlated with fire activity than simple weather parameters (Carvalho et al. 2008, Tanskanen et al. 2008, Flannigan et al. 2009).

It was also argued that the aggregation of data on fire activity over various fuel types and climates could mask the relationship between climate, fuel type and fire activity (Westerling et al. 2003). Differences in forest types among distinct vegetation formations are also likely to stem from differences in climatic conditions or fire activities (Koutsias \& Karteris 2003, Gedalof et al. 2005). Since fire activity, at large scale, depends on resource gradients of e.g., primary productivity (Krawchuk \& Moritz 2011), different climatic and vegetation zones are expected to reveal differences in fire activity (Dwyer et al. 2000). Similarly, different potential natural vegetation units at national scale may reflect different fire-related characteristics (Vázquez et al. 2002). Vegetation types or formations directly depend on abiotic factors controlling primary productivity, as for example climate, topography and soil characteristics (Gavilán \& Fernádez-González 1997, Bohn et al. 2000). Thus, classification of the study area examined on the basis of vegetation types may help exploring fire activity in a more comprehensive way instead of considering administrative units, including various types of non-ecological divisions (Vázquez et al. 2002).

Understanding and quantifying the components that shape fire regimes and influence fire activity may provide the basis for predicting possible future changes in fire activity (Zumbrunnen et al. 2011), especially when an increase in fire risk is expected, at least in the Mediterranean region (Moriondo et al. 2006). Weather parameters linked to various components of fire regime (especially number of recorded fires and burned area) have been studied worldwide, as for instance in north America (Littell et al. 2009, Hessl 2011, Littell \& Gwozdz 2011), in western Mediterranean basin (Piñol et al. 1998, Pausas 2004, Carvalho et al. 2008, Viedma et al. 2009, Pausas \& Paula 2012). In Greece, except for some studies at landscape (Kalabokidis et al. 2007) or regional (Vasilakos et al. 2009) scale, only Dimitrakopoulos et al. (2011b) and Koutsias et al. (2013) have explored changes in fire regime and their correlation with the Standardized Precipitation Index (SPI) and various weather parameters, respectively.

In this study, we explored trends and differences in fire activity (fire number, area 


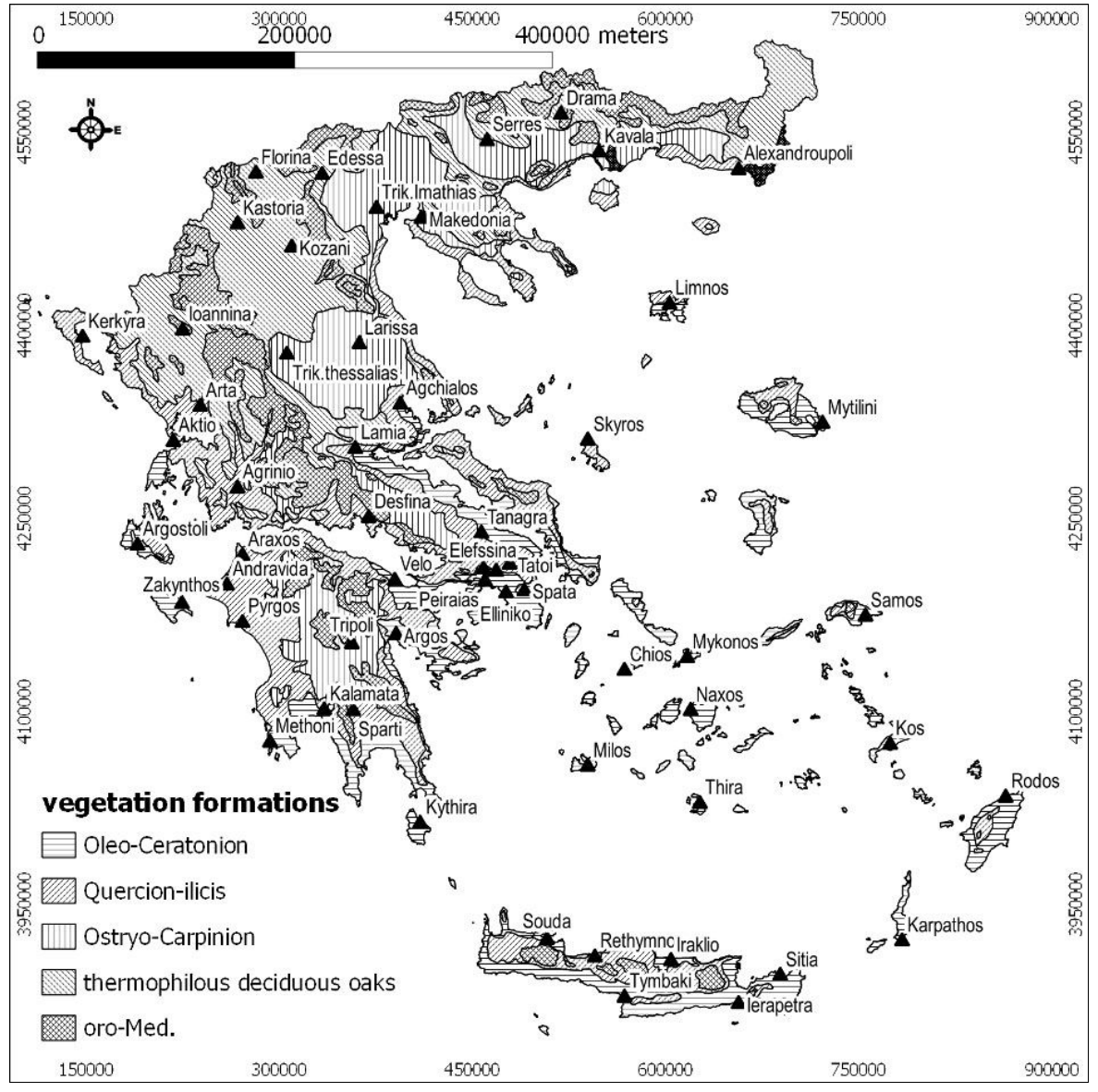

Fig. 1 - Potential distribution of forest formations and locations of the weather stations (black triangles) in Greece. Coordinate reference system: GGRS' 87 (epsg id:2100).

burned and fire ignition index) for the period 1985-2004 among different vegetation formations occurring in Greece (Mavromatis 1980). Fire ignition index (FII) is defined as the ratio between area burned and number of fires (Iliadis et al. 2002). Correlations between weather variables/indexes and fire activity were estimated taking also into consideration possible lagged effects. The results may provide the basis for the identification of important weather variables that correlate with fire activity as a basis to build up future prediction models.

\section{Material and methods}

\section{Weather data}

Meteorological data from 57 weather stations, scattered throughout Greece (Fig. 1), for the period between 1960 and 2004 were obtained from the Hellenic National Meteorological Service (HNMS). The meteorological observations from the weather stations included monthly values of mean, mean maximum and mean minimum air temperature $\left({ }^{\circ} \mathrm{C}\right)$ and monthly precipitation totals $(\mathrm{mm})$. Furthermore, monthly precipitation totals were aggregated in: fire-season (July-September); annual; spring (March-May); and winter-spring (January-May) totals. Annual and fire-season mean air temperature were also calculated. These variables were additionally used to estimate several other indexes that could potentially describe climatic or weather features combining temperature and precipitation patterns. These indexes included: (i) Giacobbes's indice d'arido- humidité (G); (ii) Emberger's indice pluviothérmique (Tuhkanen 1980); (iii) the area of the Walter \& Lieth climatic diagram for the period when precipitation curve undercuts the respective curve of air temperature (arid season - Walter \& Lieth 1967); (iv) the annual and fire-season moisture deficit, estimated by applying the monthly soil water balance model as described by $\mathrm{Xu}$ (1997), using the most suitable potential evapotranspiration equations for each region as described in Kostinakis et al. (2011) and Xystrakis \& Matzarakis (2011).

\section{Fire data}

Fire data were represented by the annual number of fires and the total annual burned area observations for the period 1985-2004, and were obtained from the Greek Forest Service. Data included the geographic coordinates of the ignition points, therefore, could describe fire events within a spatially explicit framework.

Fire activity and weather in the vegetation formations

Based on their geographic coordinates, fire data were assigned to different vegetation formations occurring in Greece (Fig. 1 Mavromatis 1980). Briefly, these formations are described in terms of their dominant/ abundant woody taxa and their distribution over Greece (Gouvas \& Sakellariou 2011). A rough correspondence of some of these formations to the distribution of the major types of Mediterranean ecosystem is reported in Arianoutsou (1998). The altitudinal distribution of the aforementioned vegetation formations on the basis of 10000 samples randomly distributed over the area covered by each formation is presented in Fig. 2. The total number of points within each formation was proportional its total area. Elevation values were obtained by the 7.5 arc-seconds Global Multi-resolution Terrain Elevation Data 2010 (GMTED2010) freely available from the United States

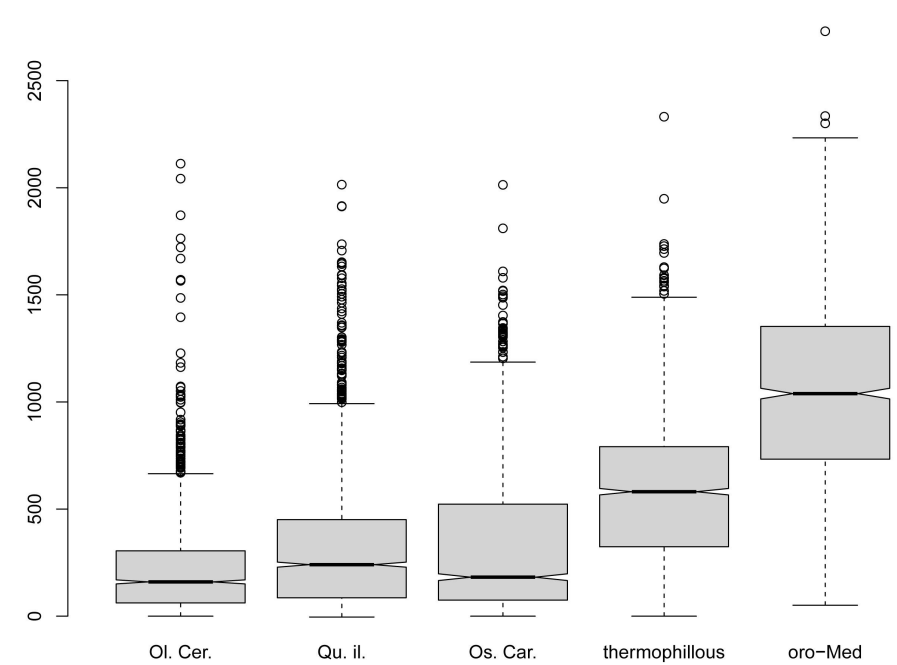

Fig. 2 - Elevation distribution of vegetation formations in Greece. (Ol.Cer.): Oleo-Ceratonion; (Qu.il.): Quercion ilicis; (Os.Car.): Ostryo-Carpinion; (thermophilous): thermophilous deciduous oaks formation; (oro-Med): oro-Mediterranean formation. 

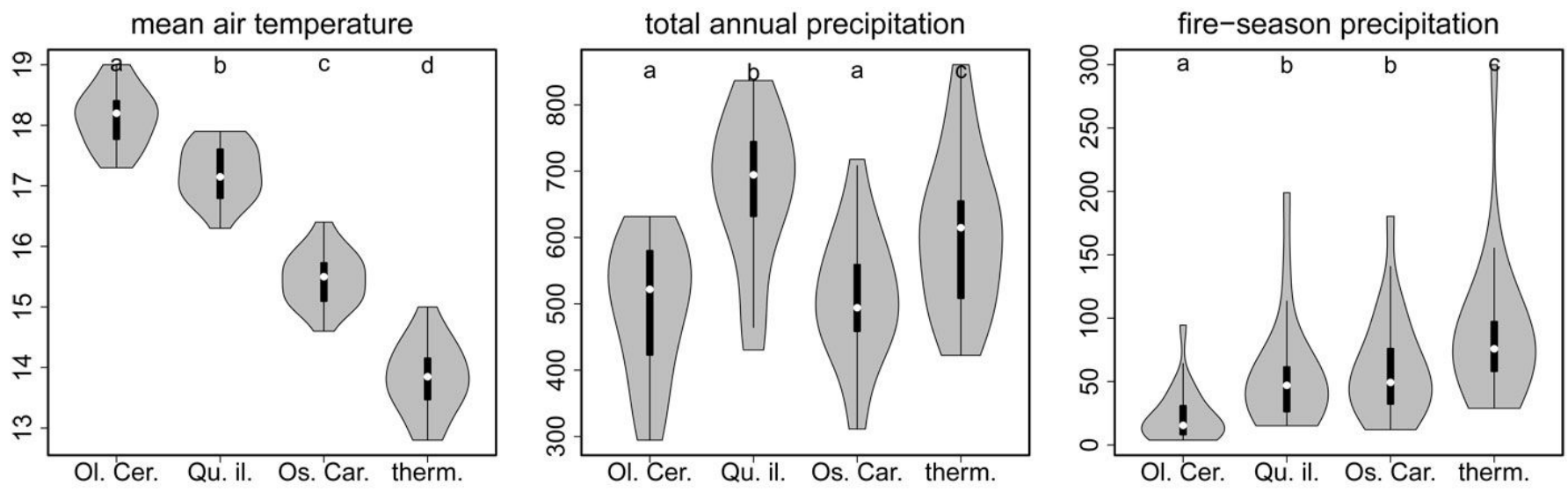

Fig. 3 - Violin plots of mean annual air temperature (left), total annual precipitation (center) and fire-season precipitation (right) of the four vegetation formations considered in this study. Different letters indicate significant differences between vegetation types according to the paired Mann-Whitney test. For vegetation types' labels, see Fig. 2.

Geological Survey (USGS - http://eros.usgs. gov/).

The Oleo-Ceratonion is the warmest-driest subtype (eu-Mediterranean) of the formation of evergreen-broadleaved shrubs. This subtype includes mainly shrublands dominated by Pistacia lentiscus, Olea europaea var. sylvestris and Ceratonia siliqua or forests made up with Pinus halepensis and P. brutia with shrublayer of the aforementioned broadleaved-evergreen taxa. Phrygana (garrigues) are also included within this formation. It is mainly distributed over the coastal areas of the southern part of the country, including coastal Crete, south Attica, south Peloponnese and Aegean islands. It occurs at low altitudes, up to $700 \mathrm{~m}$. a.s.l. (Fig. 2).

The Quercion ilicis is the "humid" subtype of the formation of evergreen broadleaved shrubs. This includes mainly Quercus ilex, Arbutus unedo shrublands or forests of $P$. halepensis and $P$. brutia with shrublayer of the aforementioned evergreen broadleaved taxa. It is distributed in the lowland part of northern Greece or inland Crete, N. Attica, eastern Peloponnese and widely in the humid western Greece. It is generally distributed at higher elevation than Oleo-Ceratonion (Fig. 2).

The Ostryo-Carpinion is the cooler subtype (sub-Mediterranean) of the formation of evergreen broadleaved shrubs. This includes mainly Quercus coccifera, Phillyrea latifolia, Acer sempervirens dominated shrubs or forests of $P$. halepensis and $P$. brutia with shrublayer of the aforementioned evergreen broadleaved taxa. It is argued that OleoCeratonion is a degraded stage of the formation of thermophilous deciduous oaks (Gouvas \& Sakellariou 2011). It is distributed in the inland-lowland part of central and northern Greece, including Thessalia and Macedonia planes and a considerably large part of the central Peloponnese. Its elevation distribution is very similar to that of Quercion ili- cis (Fig. 2), but Ostryo-Carpinion occurs at the lower altitudes in northern Greece, thus it is climatically differentiated, as also shown in Fig. 3.

The thermophilous deciduous oaks formation includes most of the deciduous broadleaved forests (Quercus frainetto, Q. Cerris, $Q$. petraea, $Q$. robur subsp. robur and Castanea sativa), occurring mainly in the mountainous zone between 300 and $800 \mathrm{~m}$ a.s.l. (Fig. 2).

Finally, the oro-Mediterranean formation includes the high-altitude forests composed by various conifers including Pinus heldreichii, $P$. sylvestris, $P$. nigra s.1., Abies $\mathrm{x}$ borisii-regis in northern Greece and Abies cephalonica and Cupressus sempervirens forests in southern Greece. It is apparent that this formation includes various ecological types over a north-to-south gradient in Greece. It includes ecosystems not subjected to frequent fires, though indications of an alteration of their fire regime, due to the combined effects of climate change and fuel accumulation, have been reported (Koutsias et al. 2012). Unfortunately, in the present study only two meteorological stations were available for this formation, and therefore it was excluded from further analysis.

A data set consisting of the annual number of fires and the annual total burned area for the period 1985-2004 for each vegetation formation was achieved. Similarly, weather data were aggregated based on vegetation formations, and seasonal or annual averages for the period 1985-2004 for each vegetation type were obtained.

\section{Analysis}

Basic descriptive statistics, including the differences among vegetation formations in the distribution of selected variables (fireand weather-related variables), were obtained from violin plots (Hintze \& Nelson 1998), drawn using the VIOPLOT package of the software R ( R Development Core Team 2011). Paired Mann-Whitney test was applied to test for differences in means of selected variables among the different vegetation formations.

Time series of fire activity in all vegetation formations were plotted alongside. To test for monotonic trends in time series of number of fires, area burned and FII, the nonparametric Mann Kendall trend test (Hipel \& McLeod 1994) was applied in the time series of all vegetation formations.

Correlation analysis was performed to describe the relationships between the annual number of fires and burned area in each vegetation type and the various weather variables aggregated on annual to seasonal basis. Correlation coefficients were also calculated between the fire characteristics of the year $t$ and weather variables for the previous three years $[\operatorname{lag}(t-1)$ up to $\operatorname{lag}(t-3)]$, since the correlation between lagged precipitation totals and burned area was often observed (Pausas 2004, Koutsias et al. 2013). To assess the significance of lagged correlations, time series of both weather and fire variables, often affected by autocorrelation, were "prewhitened" by fitting them to a $5^{\text {th }}$ order autoregressive model $\left(\mathrm{AR}_{5}\right)$, thus reducing them to "white noise" (Brockwell \& Davis 2002). Highly skewed variables, as e.g., fireseason precipitation, were log transformed and variables showing significant trends were detrended by means of ordinary least square regression against time (Cryer \& Chan 2008). All analyses were performed using the $\mathrm{R}$ statistical package (R Development Core Team 2011).

\section{Results}

Differences in weather and fire characteristics among vegetation types

Significant differences in climatic features and fire characteristics among the four vege- 

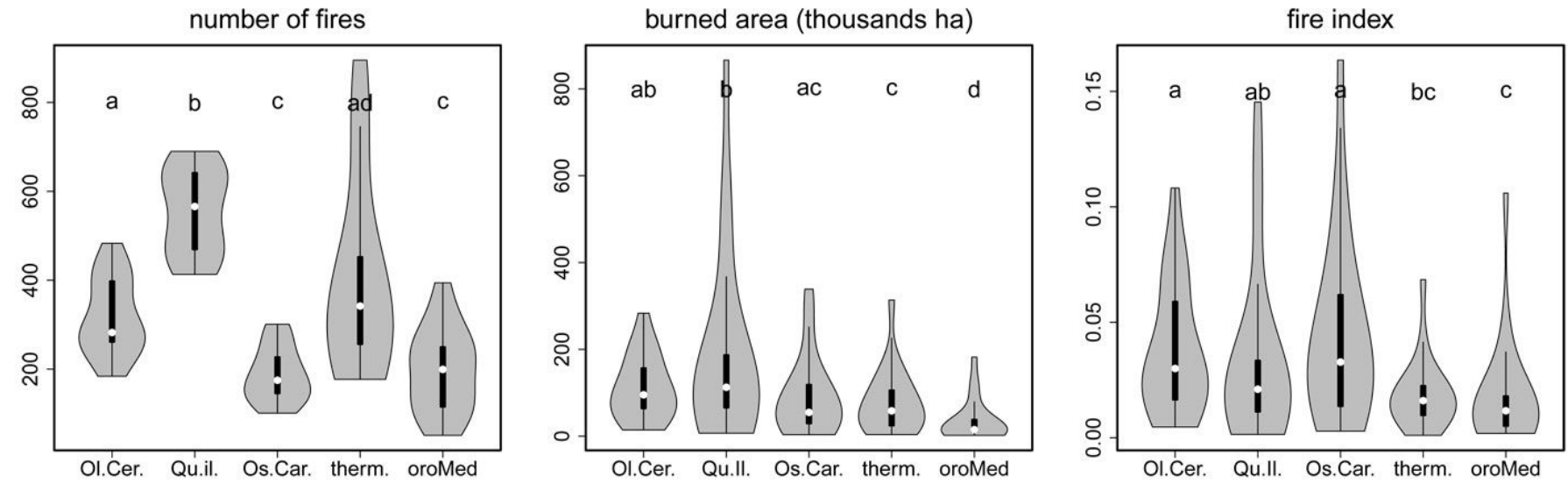

Fig. 4 - Violin plots of number of fires (left), total burned area (center) and fire ignition index (right) of the four vegetation formations con sidered in this study. Different letters indicate significant differences between vegetation types according to the paired Mann-Whitney test. For vegetation types' labels, see Fig. 2.

tation types were observed. Ostryo-Carpinion was characterized by the lowest annual number of fires, followed by oro-Mediterranean conifers. Quercion ilicis clearly showed the greatest number of fires; the thermophilous deciduous oaks formation also showed a high number of fires, though their median was lower than the median obtained for Quercion ilicis (Fig. 4). As for burned area, no significant differences among vegetation types were observed, except for the oro-Mediterranean conifers formation which clearly had the lowest burned area, as also shown from the paired-MannWhitney test (Fig. 4). Finally, patterns of fire ignition index (FII) reported in Fig. 4 indicate the presence of two main groups in Greece: (i) the Oleo-Ceratonion, Quercion ilicis and Ostryo-Carpinion formations, characterized by high values of FII; and (ii) the thermophilous deciduous oaks and oro-Mediterranean conifers, with considerably lower values of FII. To summarize, although a large number of fires was observed for the thermophilous oaks formation, their size was rather small, resulting in low values of FII; in contrast, Ostryo-carpinion was characterized by a small number of remarkably large fires that results in high values of FII.

Differences among the vegetation formations were also observed in annual mean air temperature patterns. A clear gradient form Oleo-Ceratonion (annual mean air temperature: $\sim 18{ }^{\circ} \mathrm{C}$ ) towards the thermophilous oaks (temperatures: $\sim 14{ }^{\circ} \mathrm{C}$ ) was apparent (Fig. 3). Differences in total annual rainfall were not so pronounced, though Quercion ilicis was characterized by conspicuous high values of total annual precipitation, in relation to the high annual rainfall of several weather stations from western Greece. Analogously, a clear gradient of fire-season precipitation was also obvious, with the lowest values observed in Oleo-Ceratonion and the highest in thermophilous oaks class. To summarize, Oleo-Ceratonion is characterized by high temperatures and low fire-season precipitation values, i.e., favorable conditions for fire initiation and spread; in contrast, thermophilous oaks are characterized by lower air temperature values and high values of fire-season precipitation hampering fire ignition and spread.

\section{Correlations between fire and weather variables}

Correlation analysis aimed at the detection of weather variables related to fire characteristics in all vegetation formations. Weather variables significantly correlated with fire characteristics (number of fires and burned area) are presented in Tab. 1.

Fire-season precipitation, fire-season Giaccobes' index and fire-season moisture deficit showed significant correlations with burned area in all the vegetation types analyzed (Tab. 1). Moreover, in all vegetation formations the burned area was significantly correlated with at least one weather variable or index, while the same did not hold for number of fires. Moreover, correlations coefficients between fire- and weather-related

Tab. 1 - Spearman's lag 0 correlation coefficients of number of fires and burned area observed in the vegetation formations with selected weather variables. $(\mathrm{N})$ : number of fires; $(\mathrm{A})$ : area burned; $(*)$ : significant correlation with $\mathrm{p}<0.05 ;(* *)$ : significant correlation with $\mathrm{p}<$ 0.01; $\left(\mathrm{T}_{\max }\right)$ : maximum air temperature; ( prec): precipitation; (W \& L): the area of the Walter \& Lieth climatic diagram for the period when precipitation curve undercuts the respective curve of air temperature.

\begin{tabular}{|c|c|c|c|c|c|c|c|c|c|c|c|c|}
\hline & 离 & 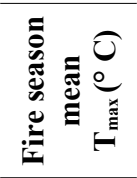 & 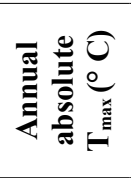 & 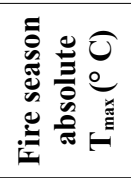 & 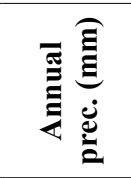 & 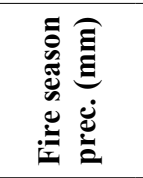 & 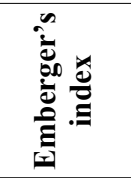 & 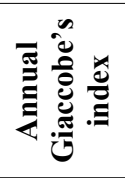 & 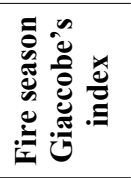 & 恶总兽 & 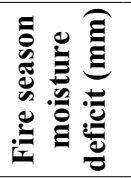 & $\infty$ \\
\hline \multirow[t]{2}{*}{ Oleo-Ceratonion } & $\mathrm{N}$ & .00339 & & 1576 & 0.04964 & & 9176 & 0.1422 & -0.04253 & 0.2941 & 0.1324 & \\
\hline & A & 3117 & 0.3623 & 5667 & .2481 & $6486^{*}$ & 0.2496 & -0.203 & $-0.6042^{* *}$ & 0.3008 & $0.4917^{*}$ & 083 \\
\hline \multirow[t]{2}{*}{ Quercion ilicis } & $\mathrm{N}$ & 2938 & & 199 & -( & & .3106 & -0.194 & & 0.2708 & 0.2317 & \\
\hline & A & & & & & & & -0.48 & & & & \\
\hline \multirow{2}{*}{$\begin{array}{l}\text { Ostryo-Carpi- } \\
\text { nion }\end{array}$} & $\mathrm{N}$ & & & & -0.3543 & $-0.5754^{* *}$ & -0.3174 & -0.1534 & & $0.6266^{* *}$ & $0.6235^{* *}$ & \\
\hline & A & 0.344 & 0.2082 & $0.4554^{*}$ & $-0.4962^{*}$ & $-0.6165^{* *}$ & $-0.4662^{*}$ & $-0.4827^{*}$ & $-0.6226^{* *}$ & 0.4421 & $0.5383^{*}$ & $0.5927^{* *}$ \\
\hline \multirow{2}{*}{$\begin{array}{l}\text { thermophillous } \\
\text { oaks }\end{array}$} & $\mathrm{N}$ & $0.5408 *$ & $0.6008^{* *}$ & $0.5937^{* *}$ & -0.3806 & $-0.6273^{* *}$ & -0.364 & -0.3558 & $-0.6138^{* *}$ & $0.6815^{* *}$ & $0.7093^{* *}$ & $0.5649 *$ \\
\hline & A & $0.6509^{* *}$ & $0.4913^{*}$ & $0.698^{* *}$ & $-0.5188^{*}$ & $-0.785^{* *}$ & $-0.5383^{*}$ & -0.3789 & $-0.7579^{* *}$ & $0.8^{* *}$ & $0.815^{* *}$ & $0.7865^{* *}$ \\
\hline
\end{tabular}



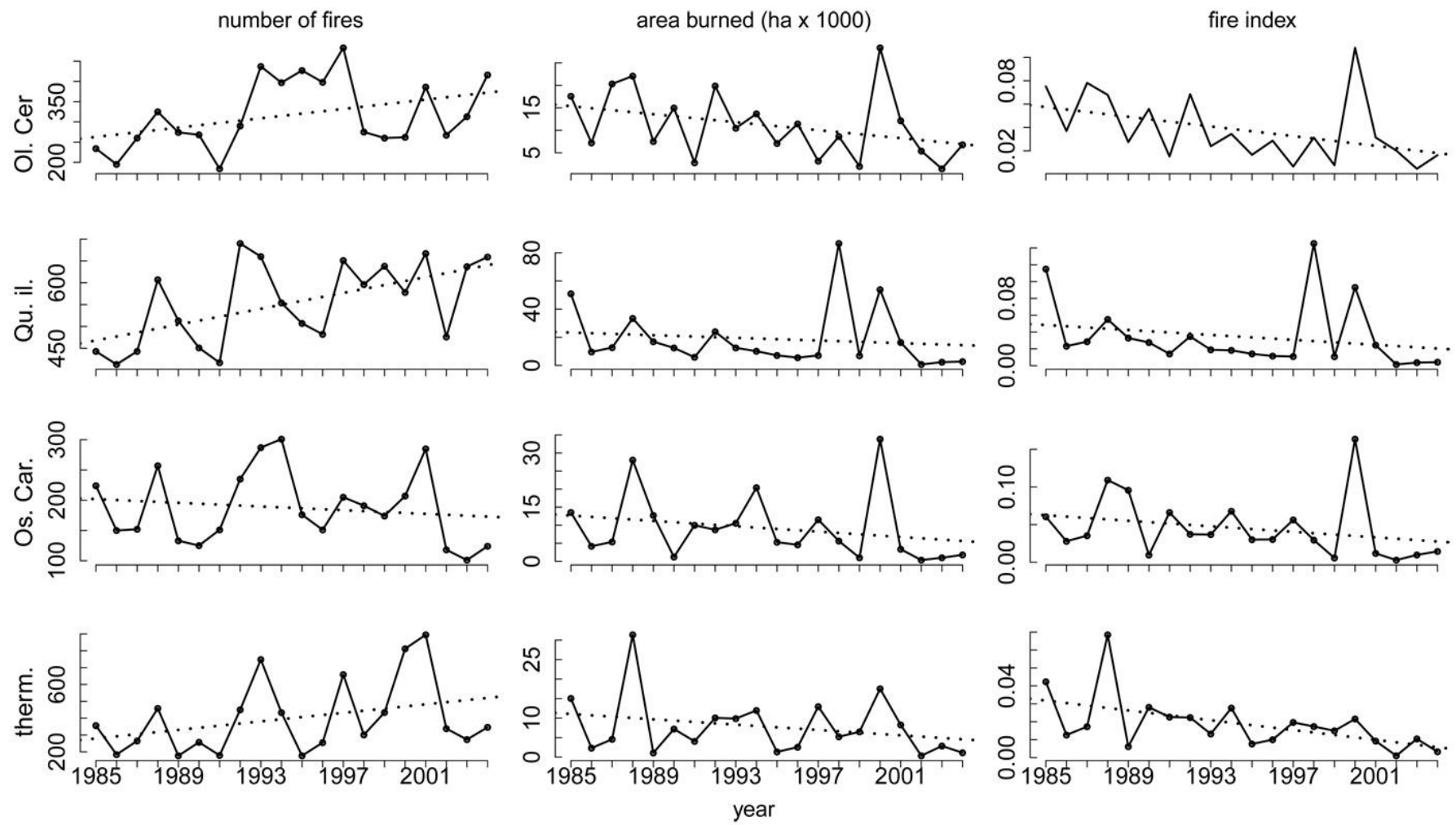

Fig. 5 - Time series of recent fire history (number of fires - left, burned area - center, and fire ignition index - right) for the vegetation forma tions considered in this study.

variables were greater in the "thermophilous deciduous oaks" formation. Interestingly, weather variables aggregated over the fire season largely exceeded all other variables as for correlation coefficients. This suggests a straightforward effect of fire-season weather on fire occurrences. Finally, rainfall-related variables generally showed larger correlation coefficients than temperature-related variables.

\section{Time series of recent fire history}

\section{Oleo-Ceratonion}

Time series of recent fire history for the Oleo-Ceratonion formation are presented in Fig. 5. Mann-Kendall trend test revealed a positive - though not significant $(\mathrm{p}=0.09)$ trend for the number of fires, but significant negative trends for the burned area $(p=0.04)$ and FII ( $\mathrm{p}=0.01)$.

The number of fires did not correlate with any of the examined weather variables; in contrast, burned area was significantly negatively correlated with lag 0 fire-season precipitation, fire-season Giaccobe's index and fire season moisture deficit (Tab. 1). Correlation analysis of lagged variables revealed a general trend of positive though not significant cross-correlations between burned area and (i) winter-spring and (ii) fire-season precipitation (Fig. 6). Furthermore, there is a series of positive cross-correlations between area burned and total annual precipitation lag 1 to lag 4 .

\section{Quercion ilicis}

Man-Kendall trend test revealed that all variables show significant trends during the period 1985-2004 (Fig. 5). The trend was positive for the parameter number of fires $(\mathrm{p}=0.027)$, and negative for area burned $(p=0.029)$ and FII $(p=0.004)$. The highest number of fires was recorded in the year 1992, while the largest burned area was observed in 1988. Similarly to Oleo-Ceratonion, the number of fires did not show any significant lag 0 correlations with weather variables (Tab. 1). In contrast, burned area was significantly correlated with most of the variables considered and had the highest (in absolute values) correlation coefficient with the arid-period area of the Walter and Lieth diagram. In Quercion ilicis, similarly to Oleo-Ceratonion, a significant correlation between area burned and lag 0 fire-season precipitation was observed, and a positive lag 3 cross correlation with winter-spring precipitation (Fig. 6). It is also interesting to observe the lag 1 positive, though not significant, correlation with spring precipitation (Fig. 6).

\section{Ostryo-Carpinion}

The recent fire history of Ostryo-Carpinion is presented in Fig. 5. The Mann-Kendall trend test revealed that all variables have decreasing trends during the period 1985-2004, though the variable number of fires was not significant $(\mathrm{p}=0.516)$. In contrast, trends for burned area $(\mathrm{p}=0.047)$ and FII $(\mathrm{p}=0.040)$ were both significant. The highest number of fires was observed during the year 1994, while the highest burned area was recorded in the year 2000 .

In contrast with vegetation formations previously examined, the number of fires of Ostryo-Carpinion showed significant correlations with various weather variables (Tab. 1). The highest correlation coefficient was observed with fire-season Giaccobe's index. Similarly, burned area was also correlated with several weather-related variables. Among temperature-related variables, a significant positive correlation with fire-season absolute maximum air temperature was observed. Among precipitation-related variables, fire-season Giaccobe's index had the highest significant negative correlation.

Correlation analysis of lagged variables revealed significant correlation coefficients between: (i) burned area and lag 0 fireseason precipitation; (ii) lag 0 cross-correlation and annual precipitation (Fig. 6). Finally, a significant positive correlation between burned area and lag 2 total annual precipitation was detected, as well as a series of positive correlations (though not significant) with fire-season precipitation up to lag 3 . 

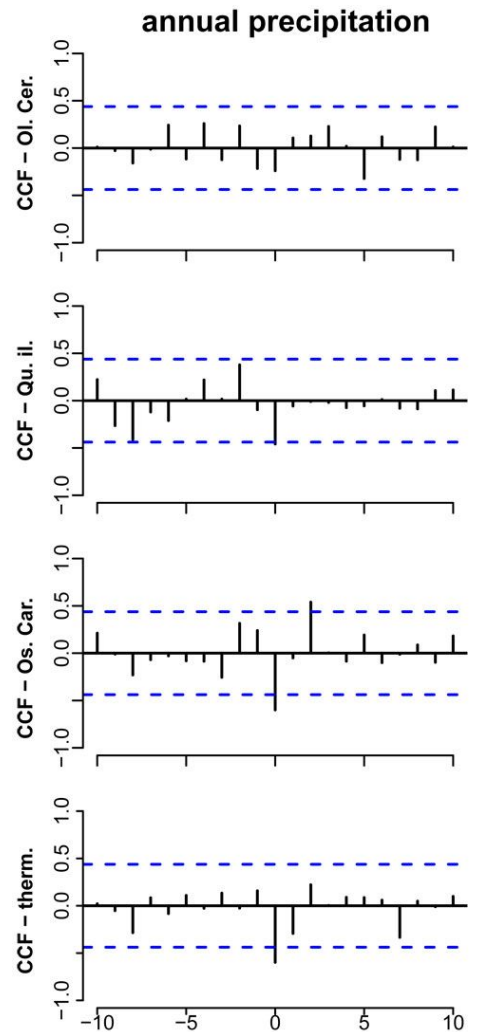

fire-season precipitation
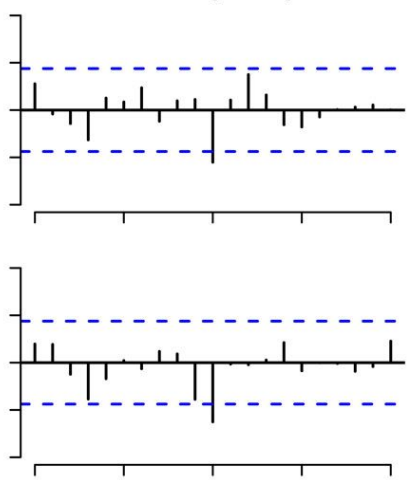

spring-precipitation
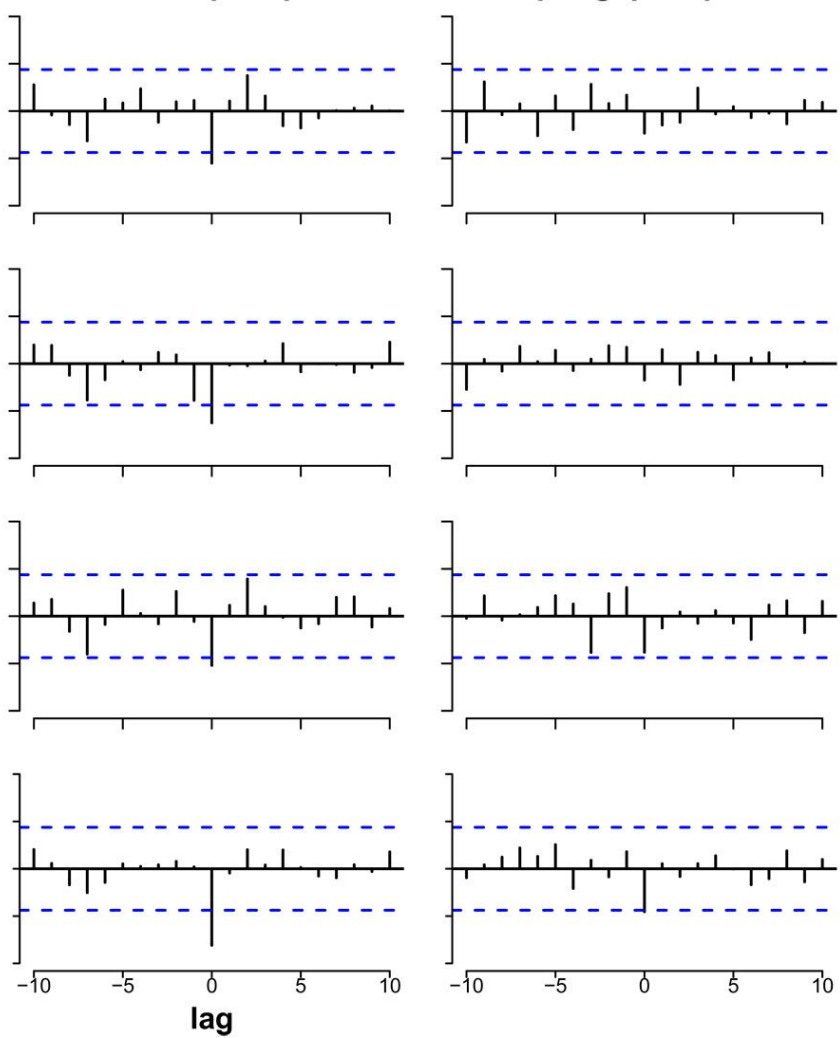

Fig. 6 - Lagged cross-correlations between burned area and annual, fire-season and spring precipitation for the vegetation formations studied. (CCF): cross-correlation function.

\section{Thermophilous deciduous oaks}

Mann-Kendall trend test revealed that both the positive trend for number of fires and the negative trend for burned area (Fig. 5) were not significant $(\mathrm{p}=0.19$ and $\mathrm{p}=0.455$, respectively); in contrast, the observed trend for FII was significant $(p=0.018)$ over the period 1985-2004. The highest number of fires was observed during the year 2001, while the largest burned area was recorded in 1988. Similarly to Ostryo-Carpinion, number of fires was significantly correlated with a number of air temperature- and precipitation-related variables: the highest correlation value was observed for the variable fire-season moisture deficit (Tab. 1). The same variable was also found to have the highest correlation coefficient (in absolute values) with the burned area.

In this forest formation, the lag 0 correlations with all examined weather variables were significantly negative (Fig. 6). There are also peaks of high, positive cross-correlations (though not significant) between burned area and lag 2 annual precipitation, and a peak of high, negative (though not significant) cross correlation with lag 1 annual precipitation.

\section{Discussion}

Based on the results obtained in this study, the number of fires in recent years showed an increasing trend for all the forest formations analyzed, with the exception of Ostryo-
Carpinion. In contrast, both burned area and fire ignition index (FII) consistently show a decreasing trend over the period 1985-2004. Therefore, a general picture of more forest fires affecting smaller areas can be drawn, suggesting an improvement in the effectiveness of fire suppression activities. Nevertheless, a large variability was observed in the above trends: years with extreme values of both number of fires and burned area are quite recurrent, and could have a pronounced effect in the trend analysis. In Greece, observations over the period 19611997 showed increasing trends for fire and weather characteristics (Dimitrakopoulos et al. 2011b). Similar increasing trends have been detected in other Mediterranean regions over the last decades (Moreno et al. 1998, Piñol et al. 1998). Furthermore, the number of fires is distinctly increasing in some regions over the last two decades, while the same does not hold for the extension of burned areas (Pausas 2004, Pausas \& Fernandez-Munoz 2012). However, it has to be pointed out that large periods of observations are required for the detection of significant trends over time, in order to ensure that the observed changes are not due to interannual weather variability.

Differences in fire activity (number of fires, burned area and FII) recorded among different vegetation formations feed the ongoing debate concerning the relative importance of fuel and weather in fire occurrence, espe- cially for large fires (Koutsias et al. 2012). The Oleo-Ceratonion formation, that mostly includes fuel-limited ecosystems, had significantly higher values of forest ignition index in comparison with the thermophilous deciduous oaks and the oro-Mediterranean conifers formations, that mostly include climate-limited ecosystems (Fig. 4). Similar considerations are supported by the output of the correlation analysis carried out (Tab. 1). The correlation between the number of fires and weather variables for the Oleo-Ceratonion and Quercion ilicis vegetation types were systematically weaker than that of Ostryo-Carpinion and thermophilous deciduous oaks. The stronger association of number of fires with the latter formations suggests that their fire history may be rather climate-controlled. Similar considerations can be argued on the basis of the analysis of the correlation coefficients between burned area and weather variables, although the differences are not so pronounced.

The lack of a direct influence of weather variables on fire ignition (number of fires) in the vegetation types Oleo-Ceratonion and Quercion ilicis also allow to hypothesize the influence of exogenous drivers in fire initiation. These formations are common in the driest part of the country and include more fire resistant (or resilient) vegetation types than the other formations. Similarly to our results, Carvalho et al. (2008) failed to detect significant regressions between fire charac- 
teristics and weather variables in a Portuguese districts characterized by fire resistant vegetation. It is also worth to notice that Oleo-Ceratonion and Quercion ilicis vegetation types include the most human-impacted ecosystems in Greece (e.g., urbanized areas and cultivated lands). Intense human impact is traditionally related with fire ignition (Moreira et al. 2010) and could alter the relationships between fire regimes and potential natural vegetation (Vázquez et al. 2002). Indeed, arsons and burn of dry biomass in cultivated land in Greece account for the large majority of fires with known ignition cause (about $49 \%$ of total number of fires over the period 1982-2006 - Tsagari et al 2011). In these areas, meteorological conditions are not the main driver of ignition for the majority of recorded fires, though weather conditions still affect the fire spread (burned area). Extreme weather conditions may counterbalance fuel limitations for fire spread (Bessie \& Johnson 1995). This is in accordance with the findings by Dimitrakopoulos et al. (2011a), who report that any fire can become large ( $>1000 \mathrm{ha}$ ) when particular meteorological conditions do occur.

In contrast, the thermophilous deciduous oaks formation suffer lower human impacts, being common at higher altitudes where land abandonment since long time led to fuel accumulation and vegetation thickening (ScOzzafava \& De Sanctis 2006, Vega-García \& Chuvieco 2006). The large amount of fue accumulated, as a consequence of the optimal climatic conditions for plant growth, may explain the large number of fires observed for this vegetation type. On the other hand, the wet fire season, as inferred by the high fire-season precipitation total (Fig. 4), may limit fire spread. These formations typically have increased fuel load requiring severe drought conditions to become flammable. Pausas \& Fernandez-Munoz (2012) argue that fire regime is a counterbalance between fuel availability and weather conditions. Fuel availability in this vegetation type increases as forest recolonization of abandoned agricultural lands comes along, partially explaining the upward trends of fires and the poor correlation observed with weather variables. This also can indirectly explain the differences observed in weather controlling fire ignition and spread in fuellimited $v s$. climate-limited vegetation formations in Greece, similarly to Pausas \& Fernandez-Munoz (2012). Nevertheless, in the case of extreme dry fire-season weather, fires in less fire-prone vegetation types (Koutsias et al. 2012) may spread uncontrollably and burn large areas to a comparable extent with other vegetation types including more fire-prone ecosystems (e.g., year 1988 - Fig. 5). A similar weather-controlled fire activity was observed for other vegetation formations characterized by climatically- controlled high fuel production, as the dry pine forests in the southwestern USA (Holden et al. 2007) or the mesic Sitka spruce forests in northwestern USA (Gedalof et al. 2005). Similarly, Mouillot et al. (2003) found that shrubs and grasslands were more probe to re-burning than forest vegetation types in Corsica. It can be argued that the relative importance of fuel in controlling fire spread diminishes in the case of extreme fire weather (Bessie \& Johnson 1995).

Among all the examined weather variables, those aggregated over fire season constantly showed higher correlation coefficients with area burned in all vegetation formations. In contrast, variables aggregated over the whole year showed considerably lower correlations. The above pattern may be due to the masking effect of contrasting season conditions in the observed fire activity (Littell et al. 2009).

Maximum air temperature and several moisture-related variables were found to be significantly correlated with area burned in Canadian peatlands (Turetsky et al. 2004). Similarly, maximum air temperature outperformed precipitation-related variables in an investigation carried out in the Iberian peninsula (Vázquez \& Moreno 1993), while the mean air temperature only marginally correlated with area burned. Consistently with our findings, mean air temperature was poorly correlated with extreme fire risk in Mediterranean regions (Good et al. 2008). The above evidence suggests a contradictory effect air temperature-related variables in summarizing the burned area variation. Indeed, in our study temperature-related variables slightly underperformed when compared to the precipitation-related variables.

Negative correlation between lag 0 spring precipitation and area burned is consistent with the results reported by Gedalof et al. (2005), who observed that an increase in the burned area may be favored when at least two consecutive dry fire seasons do occur, determining fuel desiccation and thus increasing its flammability. Similarly, winter and early spring precipitation, affecting fuel accumulation and increasing soil water content, was not clearly related to the burned area in a study carried out in Portugal, due to the conflicting mechanisms of the aforementioned processes (Viegas \& Viegas 1994).

In this study, we found one significant lagged correlation between area burned and annual precipitation for the Ostryo-Carpinion formation and some peaks in lag 2 annual and fire-season precipitation for the Oleo-Ceratonion and the thermophillous deciduous oaks formations. These findings are in accordance with those of Pausas (2004), Westerling et al. (2003) and Koutsias et al. (2013) who identified some significant effects of lagged weather parameters in the burned area. This "preconditioning" was also clearly observed in grass- and scrubland-dominated ecoprovinces in the western USA (Littell et al. 2009).

In this study drought-related indexes combining the effects of air temperature and rainfall (like the arid period area in the Walter \& Lieth diagrams or the Emberger's indice pluviothérmique) did only slightly improve fire-related variable predictions obtained using simple weather variables. The use of simple weather variables is easier to interpret providing straight forward results, and therefore it should be considered as more appropriate for the development of explanatory models of fire activity.

Some likely important factors may be missing in the results presented here. In human-impacted ecosystems, the relationships between fire and vegetation are expected to be less pronounced (Vázquez et al. 2002). Landscape structure (Viedma et al. 2009), proximity to settlements (Moreno et al. 2011), or several other socio-economic factors (Pausas \& Paula 2012, Zumbrunnen et al. 2012) are expected to influence fire ignition and spread. Such parameters have to be included in further analysis in order to explain larger part of the total variation.

The limited number of available weather stations also restricts the adoption of a more detailed classification scheme that would additionally include structural characteristics of vegetation and land-use/land cover (LULC) classes. For example, in each of the formations considered in this study, a variety of LULC types exists, including grasslands, scrublands and forests. Each of these LULC units is certainly expected to reflect different fire regimes, due to differences in fuel availability and structural characteristics (Viedma et al. 2009). Such a classification (LULC classes within forest formations) would result in complex spatial patterns requiring a denser meteorological station network in order to adequately represent the climatic and inter-annual weather variations of each class.

Efforts to include additional explanatory variables have been put forward and further analyses are expected to address the description of fire characteristics within a framework that will include vegetation, socioeconomic and landscape variability. Nevertheless, the importance of weather can not be neglected since it has been proven to account for a large part of variation in both number of fires and burned area in the Mediterranean basin (Carvalho et al. 2008) and Greece (Dimitrakopoulos et al. 2011b). Studies discussing the differences in fire regime among different ecoregions are considerably abundant in north America (Littell et al. 2009, Littell \& Gwozdz 2011), while are rather scarce in Europe (Vázquez et al. 2002). Our approach therefore, provides the basis for the better understanding of the relation between forest fires and weather and, in general, between 
fires and site productivity, since its relation to climate, topography and soil conditions (Bohn et al. 2000, Vázquez et al. 2002).

\section{Acknowledgements}

This work has been funded by the European Union's Seventh Framework Programme (FP7/2007-2013) under grant agreement $\mathrm{n}^{\circ} 243888$ (FUME project). We acknowledge the Hellenic National Meteorological Service and the Hellenic Forest Service for providing meteorological and forest fire data, respectively. The authors would like to thank M. Gouvas for his valuable insights with respect to the forest formations. We are also grateful to two anonymous reviewers for their valuable comments on an earlier version of the manuscript.

\section{References}

Arianoutsou M (1998). Aspects of demography in post-fire mediterranean plant communities of Greece. In: "Landscape Disturbance and Biodiversity in Mediterranean-Type Ecosystems" (Rundel PW, Montenegro G, Jaksic FM eds). Ecological studies, vol. 136, Springer, Berlin-Heidelberg, Germany.

Arianoutsou M (2001). Landscape changes in Mediterranean ecosystems of Greece: implications for fire and biodiversity issues. Journal of Mediterranean Ecology 2: 165-178.

Bessie WC, Johnson EA (1995). The relative importance of fuels and weather on fire behavior in sub-alpine forests. Ecology 76 (3): 747-762. doi: 10.2307/1939341

Bohn U, Gollub G, Hettwer C, Zupancic M, Puncer I, Seliškar A (2000). Map of the natural vegetation of Europe: scale 1: 2.500.000. Bundesamt für Naturschutz, Münster-Hiltrup, Germany. [in German].

Bond WJ, Woodward FI, Midgley GF (2005). The global distribution of ecosystems in a world without fire. New Phytologist 165 (2): 525-537. doi: 10.1111/j.1469-8137.2004.01252.x

Brockwell PJ, Davis RA (2002). Introduction to time series and forecasting ( $6^{\text {th }}$ edn). Springer Verlag, New York, USA.

Carvalho A, Flannigan MD, Logan K, Miranda AI, Borrego C (2008). Fire activity in Portugal and its relationship to weather and the Canadian Fire Weather Index System. International Journal of Wildland Fire 17 (3): 328-338. - doi: 10.1071/ Wf07014

Cowling RM, Rundel PW, Lamont BB, Arroyo MK, Arianoutsou M (1996). Plant diversity in Mediterranean-climate regions. Trends in Ecology and Evolution 11 (9): 362-366. - doi: 10.1016/0169-5347(96)10044-6

Cryer JD, Chan K-S (2008). Springer texts in statistics. Springer, New York, USA, pp. 249-276. doi: 10.1007/978-0-387-75959-3_11

Dimitrakopoulos A, Gogi C, Stamatelos G, Mitsopoulos I (2011a). Statistical analysis of the fire environment of large forest fires $(>1000 \mathrm{ha})$ in Greece. Polish Journal of Environmental Studies 20 (2): $327-332$
Dimitrakopoulos AP, Vlahou M, Anagnostopoulou CG, Mitsopoulos ID (2011b). Impact of drought on wildland fires in Greece: implications of climatic change? Climatic Change 109 (3-4): 331-347. - doi: 10.1007/s10584-011-0026-8

Dwyer E, Grégoire J-M, Pereira J (2000). Climate and vegetation as driving factors in global fire activity. In: "Biomass Burning and its Inter-Relationships with the Climate System" (Innes JL, Beniston M, Verstraete MM eds). Advances in Global Change Research, vol. 3, Springer, The Netherlands, pp. 171-191. - doi: 10.1007/0-30647959-1 10

Flannigan M, Stocks B, Turetsky M, Wotton M (2009). Impacts of climate change on fire activity and fire management in the circumboreal forest. Global Change Biology 15 (3): 549-560. doi: 10.1111/j.1365-2486.2008.01660.x

Gavilán R, Fernández-González F (1997). Climatic discrimination of Mediterranean broad-leaved sclerophyllous and deciduous forests in central Spain. Journal of Vegetation Science 8 (3): 377 386. - doi: $10.2307 / 3237327$

Gedalof Z, Peterson DL, Mantua NJ (2005). Atmospheric, climatic, and ecological controls on extreme wildfire years in the northwestern United States. Ecological Applications 15 (1): 154-174. - doi: 10.1890/03-5116

Good P, Moriondo M, Giannakopoulos C, Bindi M (2008). The meteorological conditions associated with extreme fire risk in Italy and Greece: relevance to climate model studies. International Journal of Wildland Fire 17 (2): 155-165. - doi: 10.1071/WF07001

Gouvas M, Sakellariou N (2011). Climate and forest vegetation in Greece. National Observatory of Athens, Athens, Greece. [in Greek]

Hessl AE (2011). Pathways for climate change effects on fire: models, data, and uncertainties. Progress in Physical Geography 35 (3): 393-407. - doi: 10.1177/0309133311407654

Hintze JL, Nelson RD (1998). Violin plots: a box plot-density trace synergism. American Statistician 52 (2): 181-184.

Hipel KW, McLeod AI (1994). Time series modelling of water resources and environmental systems. Elsevier, Amsterdam, The Netherlands.

Holden ZA, Morgan P, Crimmins MA, Steinhorst RK, Smith AMS (2007). Fire season precipitation variability influences fire extent and severity in a large southwestern wilderness area, United States. Geophysical Research Letters 34 (16): 15. - doi: 10.1029/2007g1030804

Iliadis LS, Papastavrou AK, Lefakis PD (2002). A computer-system that classifies the prefectures of Greece in forest fire risk zones using fuzzy sets. Forest Policy and Economics 4 (1): 43-54. - doi: 10.1016/S1389-9341(01)00079-X

Kalabokidis KD, Koutsias N, Konstantinidis P, Vasilakos C (2007). Multivariate analysis of landscape wildfire dynamics in a Mediterranean ecosystem of Greece. Area 39 (3): 392-402. doi: $10.1111 / j .1475-4762.2007 .00756 . x$

Kostinakis K, Xystrakis F, Theodoropoulos K, Stathis D, Eleftheriadou E, Matzarakis A (2011). Estimation of reference potential evapotranspira- tion with focus on vegetation science - the EmPEst software. Journal of Irrigation and Drainage Engineering 137 (9): 616-619. - doi: 10.1061/ (ASCE)IR.1943-4774.0000335

Koutsias N, Arianoutsou M, Kallimanis AS, Mallinis G, Halley JM, Dimopoulos P (2012). Where did the fires burn in Peloponnisos, Greece the summer of 2007? Evidence for a synergy of fuel and weather. Agricultural and Forest Meteorology 156 (1): 41-53. - doi: 10.1016/j.agrformet.2011.12.006

Koutsias N, Karteris M (2003). Classification analyses of vegetation for delineating forest fire fuel complexes in a Mediterranean test site using satellite remote sensing and GIS. International Journal of Remote Sensing 24 (15): 3093-3104. doi: 10.1080/0143116021000021152

Koutsias N, Xanthopoulos G, Founda D, Xystrakis F, Nioti F, Pleniou M, Mallinis G (2013). On the relationships between forest fires and weather conditions in Greece from long-term national observations (1894-2010). International Journal of Wildland Fire. [in press] - doi: 10.1071/ WF12003

Krawchuk MA, Moritz MA (2011). Constraints on global fire activity vary across a resource gradient. Ecology 92: 121-132. - doi: 10.1890/ 09-1843.1

Littell JS, Gwozdz RB (2011). Climatic water balance and regional fire years in the Pacific Northwest, USA: linking regional climate and fire at landscape scales. In: "The Landscape Ecology of Fire" (McKenzie D, Miller C, Falk DA eds). Ecological studies, vol. 123, Springer Science and Business Media BV, New York, USA. - doi: 10.1007/978-94-007-0301-8 5

Littell JS, McKenzie D, Peterson DL, Westerling AL (2009). Climate and wildfire area burned in western US ecoprovinces, 1916-2003. Ecological Applications 19 (4): 1003-1021. - doi: 10.1890/ 07-1183.1

Mavromatis G (1980). The bioclimate of Greece: relations between climate and natural vegetation, bioclimatic maps. Forest Research 1: 1-63. [in Greek]

Moreira F, Catry F, Rego F, Bacao F (2010). Sizedependent pattern of wildfire ignitions in Portugal: when do ignitions turn into big fires? Landscape Ecology 25 (9): 1405-1417. - doi: 10.1007/s10980-010-9491-0

Moreira F, Viedma O, Arianoutsou M, Curt T, Koutsias N, Rigolot E, Barbati A, Corona P, Vaz P, Xanthopoulos G, Mouillot F, Bilgili E (2011). Landscape - wildfire interactions in southern Europe: Implications for landscape management. Journal of Environmental Management 92 (10): 2389-2402. - doi: 10.1016/j.jenvman.2011.06. 028

Moreno JM, Vázquez A, Veléz R (1998). Recent history of forest fires in Spain. In: "Large Forest Fires" (Moreno JM ed). Backhuys Publishers, Leiden, The Netherlands, pp. 159-185.

Moreno JM, Viedma O, Zavala G, Luna B (2011). Landscape variables influencing forest fires in central Spain. International Journal of Wildland Fire 20 (5): 678-689. - doi: 10.1071/Wf10005 
Moriondo M, Good P, Durao R, Bindi M, Giannakopoulos C, Corte-Real J (2006). Potential impact of climate change on fire risk in the Mediterranean area. Climate Research 31 (1): 85-95. doi: $10.3354 / \mathrm{cr} 031085$

Mouillot F, Ratte JP, Joffre R, Moreno JM, Rambal S (2003). Some determinants of the spatio-temporal fire cycle in a Mediterranean landscape (Corsica, France). Landscape Ecology 18 (7): 665-674. - doi: 10.1023/B:LAND.00000041 82.22525.a9

Pausas JC, Llovet J, Rodrigo A, Vallejo R (2008). Are wildfires a disaster in the Mediterranean basin? A review. International Journal of Wildland Fire 17 (6): 713-723. - doi: 10.1071/ Wf07151

Pausas JG (2004). Changes in fire and climate in the eastern Iberian peninsula (Mediterranean basin). Climatic Change 63 (3): 337-350. - doi: 10.1023/B:CLIM.0000018508.94901.9c

Pausas JG, Fernandez-Munoz S (2012). Fire regime changes in the western Mediterranean basin: from fuel-limited to drought-driven fire regime. Climatic Change 110 (1-2): 215-226. doi: 10.1007/s10584-011-0060-6

Pausas JG, Paula S (2012). Fuel shapes the fireclimate relationship: evidence from Mediterranean ecosystems. Global Ecology and Biogeography 21 (11): 1074-1082. - doi: 10.1111/ j.1466-8238.2012.00769.x

Piñol J, Terradas J, Lloret F (1998). Climate warming, wildfire hazard, and wildfire occurrence in coastal eastern Spain. Climatic Change 38 (3): 345-357. - doi: 10.1023/A:10053166 32105

R Development Core Team (2011). R: a language and environment for statistical computing (2.14.0 edn). Vienna, Austria.

Rundel PW (1981). Fire as an ecological factor. In: "Physiological Plant Ecology. I. Responses to the Physical Environment" (Lange OL, Nobel PS, Osmond CB, Ziegler H eds). Springer-Verlag, Berlin, Germany, pp. 501-538.

Scozzafava S, De Sanctis A (2006). Exploring the effects of land abandonment on habitat struc- tures and on habitat suitability for three passerine species in a highland area of Central Italy. Landscape and Urban Planning 75 (1-2): 23-33. - doi: 10.1016/j.landurbplan.2004.10.006

Tanskanen X, Heidi X, Ven X, Inen X, Ari X (2008). The relationship between fire activity and fire weather indices at different stages of the growing season in Finland. Vol. 13, Finnish Environment Institute, Helsinki, Finland.

Tsagari K, Karetsos G, Proutsos N (2011). Forest fires in Greece, 1983-2008. WWF Hellas, NAGREF-IMFE \& TFP, Athens, Greece.

Tuhkanen S (1980). Climatic parameters and indices in plant geography. Acta Phytogeogrica Suecica, vol. 67, Almqvist \& Wiksell International, Sweden.

Turetsky MR, Amiro BD, Bosch E, Bhatti JS (2004). Historical burn area in western Canadian peatlands and its relationship to fire weather indices. Global Biogeochemical Cycles 18 (4): 1-9. - doi: 10.1029/2004gb002222

Vasilakos C, Kalabokidis K, Hatzopoulos J, Matsinos I (2009). Identifying wildland fire ignition factors through sensitivity analysis of a neural network. Natural Hazards 50 (1): 125143. - doi: 10.1007/s11069-008-9326-3

Vázquez A, Moreno JM (1993). Sensitivity of fire occurrence to meteorological variables in mediterranean and atlantic areas of Spain. Landscape and Urban Planning 24 (1-4): 129-142. - doi: 10.1016/0169-2046(93)90091-Q

Vázquez A, Pérez B, Fernández-González F, Moreno JM (2002). Recent fire regime characteristics and potential natural vegetation relationships in Spain. Journal of Vegetation Science 13 (5): 663-676. - doi: 10.1111/j.1654-1103.2002. tb02094.x

Vega-García C, Chuvieco E (2006). Applying local measures of spatial heterogeneity to LandsatTM images for predicting wildfire occurrence in Mediterranean landscapes. Landscape Ecology 21 (4): 595-605. - doi: 10.1007/s10980-0054119-5

Viedma O (2008). The influence of topography and fire in controlling landscape composition and structure in Sierra de Gredos (Central Spain). Landscape Ecology 23 (6): 657-672. doi: 10.1007/s10980-008-9228-5

Viedma O, Angeler DG, Moreno JM (2009). Landscape structural features control fire size in a Mediterranean forested area of central Spain. International Journal of Wildland Fire 18 (5): 575-583. - doi: 10.1071/Wf08030

Viegas DX, Viegas MT (1994). A relationship between rainfall and burned area for Portugal. International Journal of Wildland Fire 4 (1): 11-16. - doi: 10.1071/WF9940011

Walter H, Lieth H (1967). Klimadiagram-Weltatlas. VEB Gustav Fischer Verlag, Jena, Germany. [in German]

Westerling AL, Gershunov A, Brown TJ, Cayan DR, Dettinger MD (2003). Climate and wildfire in the western United States. Bulletin of the American Meteorological Society 84 (5): 595604. - doi: 10.1175/Bams-84-5-595

Xu CY (1997). Application of water balance models to different climatic regions of China for water resources assessment. Water Resources Management 11: 51-67. - doi: 10.1023/A:1007945 406728

Xystrakis F, Matzarakis A (2011). Evaluation of 13 empirical reference potential evapotranspiration equations on the island of Crete in southern Greece. Journal of Irrigation and Drainage Engineering 137 (4): 211-222. - doi: 10.1061/ (ASCE)IR.1943-4774.0000283

Zumbrunnen $\mathrm{T}$, Menéndez $\mathrm{P}$, Bugmann $\mathrm{H}$, Conedera M, Gimmi U, Bürgi M (2012). Human impacts on fire occurrence: a case study of hundred years of forest fires in a dry alpine valley in Switzerland. Regional Environmental Change 12 (4): 935-949. - doi: 10.1007/s10113-012-0307-4 Zumbrunnen T, Pezzatti GB, Menendez P, Bugmann H, Burgi M, Conedera M (2011). Weather and human impacts on forest fires: 100 years of fire history in two climatic regions of Switzerland. Forest Ecology and Management 261 (12): 2188-2199. - doi: 10.1016/j.foreco.2010.10.009 